\title{
Process Parameter Optimization in Fused Deposition Modeling (FDM) Using Response Surface Methodology (RSM)
}

Original Article

Keywords:

Posted Date: January 5th, 2021

DOI: https://doi.org/10.21203/rs.3.rs-122421/v2

License: (c) (i) This work is licensed under a Creative Commons Attribution 4.0 International License.

Read Full License 


\section{Abstract}

The authors have requested that this preprint be withdrawn due to erroneous posting.

\section{Full Text}

The authors have withdrawn this preprint from Research Square. 